JOANNA ŚWIĘTONIOWSKA

Wyższa Szkoła Informatyki i Zarządzania w Rzeszowie, Polska - University of Information Technology and Management in Rzeszow, Poland

\title{
Przedsiębiorczy gracz - jak mechanizmy grywalizacji motywują do nauki uczniów w szkole średniej?
}

\section{Entrepreneurial gamer - how do gamification mechanisms drive learning motivation of secondary school students?}

\begin{abstract}
Streszczenie: Edukatorzy wciąż poszukują metod i strategii nauczania, pozwalających zachęcić młodych ludzi do podejmowania w procesie edukacyjnym celowych i skutecznych działań, których głównym katalizatorem byłaby przede wszystkim motywacja wewnętrzna. Popularność gier komputerowych oraz ich zdolność do utrzymania zainteresowania użytkowników istotnie wpłynęły na dynamiczny rozwój i coraz szersze zastosowanie grywalizacji w dydaktyce. Celem artykułu jest prezentacja korzyści z wykorzystania metody grywalizacji w nauczaniu przedsiębiorczości na poziomie liceum ogólnokształcącego oraz wyników badań pokazujących wpływ wdrożonych mechanizmów na motywację uczniów do uczenia się i rozwijania swoich kompetencji przedsiębiorczych. W studium przypadku omówiono eksperyment $\mathrm{z}$ wdrożenia grywalizacji $\mathrm{w}$ ramach pełnego cyklu obowiązkowych zajęć $\mathrm{z}$ przedmiotu podstawy przedsiębiorczości, który został osadzony w konkretnym kontekście fabularnym - Galaktyce Enterprise. Na podstawie badań empirycznych przeprowadzonych wśród uczniów biorących udział w zgrywalizowanych zajęciach dokonano analizy i oceny czynników, które aktywizowały młodzież i zwiększały jej zaangażowanie. Czynniki te analizowano za pomocą modelu Octalysis Framework. Wyniki przeprowadzonego badania dowodzą, że czynnikami, które w największym stopniu wpływały na działania podejmowane przez uczniów, są: rozwój i osiąganie celów, strach przed utratą i zapobieganie, wpływ społeczny i nawiązywanie relacji, a także własność i posiadanie.
\end{abstract}

\begin{abstract}
Educators are constantly looking for teaching methods and strategies that would encourage young people to undertake purposeful and effective activities in the educational process, primarily driven by internal motivation. The popularity of computer games and their ability to maintain the interest of users have significantly influenced the dynamic development and wider use of gamification in didactics. The aim of the paper is to present the benefits of using the gamification method in teaching entrepreneurship at the secondary school level and the results of research showing the impact of the implemented mechanisms on the motivation of students to learn and develop their entrepreneurial competences. The case study discusses an experiment in implementing gamification as part of a full series of obligatory classes in Entrepreneurship set in a specific story context - Enterprise Galaxy.
\end{abstract}


On the basis of empirical research conducted among students participating in the classes, an analysis and evaluation of factors was made that activated the youth and increased their involvement. These factors were analysed using the Octalysis Framework model. The results of the study show that the factors that most influenced the activities undertaken by high school students are: skills development and achievement of goals, fear of loss and prevention, social influence and establishing relationships, as well as ownership and possession.

Słowa kluczowe: grywalizacja; motywacja; przedsiębiorczość

Keywords: entrepreneurship; gamification; motivation

Otrzymano: 25 października 2020

Received: 25 October 2020

Zaakceptowano: 20 kwietnia 2021

Accepted: 20 April 2021

\section{Sugerowana cytacja/Suggested citation:}

Świętoniowska, J. (2021). Przedsiębiorczy gracz - jak mechanizmy grywalizacji motywują do nauki uczniów w szkole średniej?. Przedsiębiorczość - Edukacja [Entrepreneurship - Education], 17(1), 65-76. https://orcid.org/10.24917/20833296.171.5

\section{Wstęp}

Podstawowymi efektami uczenia się w ramach kształcenia ogólnego prowadzonego m.in. w liceach ogólnokształcących są kompetencje ogólne (Kwiatkowski, 2018). To kompetencje niemające bezpośredniego związku z żadną konkretną branżą, jednakże ich posiadanie sprawia, że młody człowiek w przyszłości jest w stanie efektywnie i skutecznie wykonywać swoje obowiązki zawodowe. Jedną z takich kompetencji jest postawa przedsiębiorcza, która postrzegana jest jako główna siła napędowa rozwoju gospodarek. Podkreśla się, że kształtowanie tej postawy to działanie konieczne dla rozwoju gospodarki w obszarach postępu technologicznego, technicznego, ekonomicznego, społecznego, kulturowego czy politycznego (Zioło, 2012: 18).

Postawy przedsiębiorcze powinny być kształtowane już od pierwszego roku edukacji wczesnoszkolnej we wszystkich formach i następnie rozwijane na kolejnych poziomach edukacji: podstawowym, średnim i wyższym (Wach, Głodowska, 2019). Jednym z poważniejszych wyzwań, w obliczu których stoi współczesny system edukacyjny, jest zwiększenie motywacji do nauki i zaangażowania młodych ludzi urodzonych w XXI w.

Niniejszy artykuł opiera się na eksperymencie z wdrożenia grywalizacji w ramach pełnego, rocznego cyklu obowiązkowych zajęć z przedmiotu podstawy przedsiębiorczości, prowadzonych w liceum ogólnokształcącym. Celem artykułu jest zbadanie wpływu wdrożonych mechanizmów grywalizacyjnych na motywację uczniów do uczenia się i rozwijania kompetencji przedsiębiorczych. W pierwszej części artykułu omówiono zagadnienia dotyczące wyzwań współczesnej edukacji w zakresie kształcenia przedsiębiorczości. W części drugiej zaprezentowano istotę grywalizacji oraz korzyści uzasadniające jej stosowanie w procesie kształcenia. Następnie przedstawiono założenia wdrożonej grywalizacji. W ostatniej części artykułu omówiono wyniki badań wpływu wdrożonych mechanizmów na motywację do uczenia się i aktywizację uczniów podczas zajęć. 


\section{Wyzwania wspótczesnej edukacji w zakresie przedsiębiorczości}

Wielu autorów podkreśla, iż kompetencje przedsiębiorcze odgrywają niezwykle istotną rolę $\mathrm{w}$ budowaniu przedsiębiorczego społeczeństwa oraz nowoczesnej gospodarki (Borowiec-Gabryś, Kilar, Piróg, 2015; Rachwał i in., 2018; Sadowska, 2016; Wach 2013, 2014; Wach, Głodowska, 2019). W związku z tym, iż w literaturze można znaleźć mnogość pojęć związanych z tym obszarem kształcenia (np. nauczanie przedsiębiorczości, kształcenie w zakresie przedsiębiorczości, edukacja dla przedsiębiorczości, edukacja przez przedsiębiorczość, edukacja o przedsiębiorczości itp.), Krzysztof Wach proponuje stosowanie szerokiego pojęcia edukacji na rzecz przedsiębiorczości, które obejmuje:

- przedsiębiorczość indywidualną i organizacyjną (rozwijanie takich postaw, jak: kreatywność, innowacyjność, inwencyjność, własna inicjatywa, komunikatywność, intraprzedsiębiorczość),

- przedsiębiorczość biznesową (rozwijanie umiejętności niezbędnych do podejmowania przedsięwzięć o charakterze biznesowym, komercyjnym i społecznym) oraz

- edukację ekonomiczną (dostarczanie wiedzy na temat otoczenia, w którym funkcjonować będzie przedsiębiorstwo) (Wach, 2014).

Jak widać, definicja ta wykracza poza ograniczone rozumienie przedsiębiorczości jako zdolności do założenia i prowadzenia własnej firmy. Obejmuje również rozwijanie cech osobowości i umiejętności, które stanowią podstawę ducha przedsiębiorczości.

W literaturze przedmiotu istnieją dwa przeciwstawne nurty rozważań na temat źródeł przedsiębiorczości. W pierwszym z nich podkreśla się, iż cechy i umiejętności przedsiębiorcze mają charakter wrodzony, natomiast w drugim - iż przedsiębiorczość można w sobie wykształcić w trakcie edukacji(Gąsiorowska-Mącznik, 2017). D.F. Kuratko uważa, że pytanie: Czy można uczyć przedsiębiorczości? jest już przestarzałe. Wskazuje on na bardziej adekwatne pytanie dotyczące edukacji w zakresie przedsiębiorczości, tj.: Czego i w jaki sposób powinno się tego uczyć? (Kuratko, 2005).

W polskim systemie edukacji nauczanie przedsiębiorczości na poziomie edukacji elementarnej dotyczy pojedynczych zagadnień będących elementem podstawy programowej różnych przedmiotów (m.in. wiedzy o społeczeństwie, języku polskim, geografii, wychowaniu do życia w rodzinie czy etyce) (Kilar, Rachwał, 2019a). Edukacja w zakresie przedsiębiorczości w formie oddzielnego przedmiotu podstawy przedsiębiorczości została wprowadzona wraz z reformą programową w roku szkolnym 2002/2003. W szkolnictwie wyższym zagadnienia przedsiębiorczości wprowadzane są na kierunkach ekonomicznych oraz menedżerskich. Na pozostałych kierunkach, takich jak kierunki humanistyczne, techniczne czy artystyczne, istnieje widoczny deficyt w tym obszarze (Sadowska, 2016). Edukacja przedsiębiorczości w Polsce, zarówno na poziomie szkół średnich, jak i szkół wyższych, jest zdominowana przez zagadnienia ekonomiczne (choć nadal jest jej za mało w polskim systemie kształcenia) (Kilar, Rachwał, 2019b; Wach, 2013). W przypadku szkół średnich treści nauczania są narzucone przez podstawę programową. Doświadczenia pokazują, iż ranga przedmiotu podstawy przedsiębiorczości na poziomie szkół średnich jest deprecjonowana głównie na rzecz przedmiotów maturalnych, a nauka przedsiębiorczości opiera się na przymusie. Niezwykle istotnym zadaniem edukatora staje się więc zbudowanie środowiska sprzyjającego zwiększaniu zaangażowania uczniów i pokazaniu im praktycznego wymiaru przedsiębiorczości. W przypadku szkół wyższych treści nauczania dobierane są elastycznie, 
np. w zależności od kierunku studiów, na którym przedmiot jest wprowadzony. Podejście takie sprzyja większej motywacji uczących się.

Predyspozycje do bycia przedsiębiorczym oraz kompetencje przedsiębiorcze mogą być znakomicie rozwijane w procesie kształcenia, jednak niezbędne jest zapewnienie ku temu sprzyjających warunków, a sam proces powinien przebiegać w doświadczeniu praktycznym (Gąsiorowska-Mącznik, 2017). Obecny klasyczny model nauczania, mający kształtować postawy przedsiębiorcze uczniów, nie jest już wystarczający w obliczu wyzwań cywilizacyjnych, które mają ogromny wpływ na współczesną edukację (Marques, Albuquerque, 2012).

W instytucjach systemu edukacji powadzona jest dyskusja na temat tego, jak zapewnić środowisko sprzyjające skutecznemu kształtowaniu kompetencji przedsiębiorczych, oraz jakie metody i narzędzia nauczania byłyby dostosowane do potrzeb młodzieży. Kluczowa jest też większa otwartość edukatorów na stosowanie w procesie dydaktycznym nieszablonowych, innowacyjnych rozwiązań.

Jednym z poważniejszych wyzwań, w obliczu których stoi wczesny system edukacji, jest zmotywowanie do nauki i zwiększenie zaangażowania w proces uczenia się młodych ludzi urodzonych w XXI wieku. Wyzwanie to staje się szczególnie istotne w dobie przenoszenia procesu edukacyjnego do internetu w związku z trwającą epidemią COVID-19. W sytuacji zamknięcia ośrodków edukacyjnych znaczącą rolę w podnoszeniu skuteczności procesu kształcenia odgrywają narzędzia i metody edukacyjne maksymalnie zwiększające zaangażowanie i motywację uczniów. Kształcenie na odległość nie może być zwykłym przesyłaniem treści edukacyjnych, lecz raczej procesem uczenia się zapewniającym uczniom swobodę, odpowiedzialność, elastyczność oraz wybór. Proces ten wymaga projektowania i określania celów edukacyjnych tak, aby stworzyć skuteczną ekologię uczenia się (Bozkurt, Sharma, 2020).

Edukacja w zakresie przedsiębiorczości w XXI w. wymaga, aby edukatorzy poszerzyli swój warsztat pedagogiczny o nowe i innowacyjne podejścia do nauczania przedsiębiorczości. W przedsiębiorczej pedagogice (dydaktyce), trzon metod nauczania sprzyjających kształtowaniu odpowiednich postaw tworzą metody aktywizujące (w tym metody problemowe, m.in. gry dydaktyczne). Osiąganie celów kształcenia wymaga zastosowania metod, które umożliwiają nabywanie umiejętności praktycznych w przyjaznym i motywującym do nauki środowisku. Metody problemowe (w tym mechanizmy wykorzystywane w grach) wyzwalają w uczących się przedsiębiorczości pożądaną postawę aktywnej inicjatywności (Wach, 2013).

\section{Korzyści zastosowania grywalizacji w edukacji}

Współczesny system edukacyjny kształci młode pokolenie - tzw. generację Alfa oraz pokolenie Z. Tej młodzieży gry komputerowe, będące cyfrowymi miejscami spotkań, często zastępują kontakty towarzyskie. Dostępność nowych konsol, platform i technologii stała się istotnym czynnikiem napędzającym ciągły wzrost zainteresowania grami. Gry stanowią koło napędowe rozwoju cywilizacyjnego i są nieodłącznym elementem kultury (Tkaczyk, 2012). Coraz większa popularność gier komputerowych oraz ich zdolność do utrzymywania zainteresowania użytkowników doprowadziły do rozwoju grywalizacji. Grywalizacją (ang. gamification) nazywamy przeniesienie mechanizmów znanych z gier (także komputerowych, choć nie tylko) do świata rzeczywistego, aby zmieniać ludzkie 
zachowania (Tkaczyk, 2012: 10). W grywalizacji elementy znane z gier (np. punkty) oraz ich cechy (np. ocenianie, wyzwania) wykorzystywane są w kontekstach innych niż gry, w celu osiągnięcia pozytywnych efektów (Barata i in., 2015; Deterding i in., 2011; Nand i in., 2019; Sánchez, Langer, Kaur, 2020).

Literatura naukowa dostarcza wielu przykładów wykorzystania grywalizacji w takich dziedzinach, jak biznes, biologia, marketing, zarządzanie czy psychologia (Connolly i in., 2012). W ciągu ostatnich lat w badaniach dotyczących sektora edukacji również widać wyraźny wzrost zainteresowania tym, jak gry mogą wpływać na proces kształcenia. W strategiach uczenia coraz popularniejsze staje się stosowanie gier zarówno wirtualnych, jak i fizycznych (Qian, Clark, 2016). Uzasadnienia dla stosowania grywalizacji można poszukiwać w modelu behawioralnym B.J. Fogga, hierarchii potrzeb A.H. Maslowa, teorii modyfikacji zachowań B.F. Skinnera oraz teorii wewnętrznej motywacji D. Pinka (Kachniewska, 2015: 37). Każda czynność, która wiąże się z zabawą, automatycznie angażuje użytkownika. Jest to związane z naturą człowieka (Kumar, Khurana, 2012).

W literaturze szeroko opisane są również korzyści, których oczekuje się od grywalizacji. Wskazuje się, iż uczenie z wykorzystaniem mechanizmów gier może być efektywniejsze od tradycyjnego nauczania w klasie, ponieważ zapewnia możliwości odkrywania i zdobywania nowej wiedzy oraz umiejętności, przy jednoczesnym zwiększeniu motywacji do uczenia się (Boyle i in., 2014) oraz stawia ucznia w bardziej aktywnej roli w porównaniu z tradycyjnymi metodami (Qian, Clark, 2016). Jedną z najczęściej wymienianych zalet grywalizacji jest zwiększenie motywacji do uczenia się i zaangażowania uczniów (Boyle i in., 2014), gdyż wyzwala ona ciekawość, wywołuje i utrzymuje zaangażowanie, skuteczniej przekonuje do podjęcia działania, zwiększa efektywność oraz poprawia wydajność pracy (Kaźmierczak, 2016)

Zauważono, że pomimo rosnącego w ostatnich latach zainteresowania grywalizacją w edukacji, powszechne jest wykorzystywanie gier w klasie, natomiast dopiero niedawno zaczęto badać możliwość uczynienia całego przedmiotu za pomocą gry (czyli zastosowania pełnej grywalizacji przedmiotu czy kursu) (Hanus, Fox, 2015).

\section{Przykład zastosowania grywalizacji na lekcjach z podstaw przedsiębiorczości}

Grywalizacji został poddany przedmiot podstawy przedsiębiorczości, który wdrożono w roku szkolnym 2019/2020 w Akademickim Liceum Ogólnokształcącym w Rzeszowie. W zajęciach uczestniczyły dwie klasy pierwsze o różnych profilach (profil zdrowie i farmacja oraz profil technologie informacyjne) - łącznie 57 uczniów w wieku 16 lat. Grywalizacja przedmiotu polegała na przemodelowaniu go w taki sposób, aby przypominał grę, która została nazwana Galaktyka Enterprise. Celem zmian wdrożonych w przedmiocie nie było incydentalne wykorzystanie gier edukacyjnych (planszowych, komputerowych itp.) definiowane w literaturze przedmiotu jako kształcenie oparte na grach (ang. Game-Based Learning), lecz przekształcenie całych zajęć z podstaw przedsiębiorczości w grę. Grywalizacji podlegał cały cykl zajęć, realizowany w wymiarze 60 godz. lekcyjnych dla każdej z grup przez cały rok szkolny.

Przedmiot osadzony został w konkretnym kontekście fabularnym - toczącej się wojny w tytułowej Galaktyce Enterprise pomiędzy Planetami (ich rolę odgrywali uczniowie) skupionymi wokół Przywódczyni Planety Saint-1 w Mgławicy Aureola (jej rolę odgrywał nauczyciel) a złowrogim Imperium. Planety, które chciały oprzeć się Imperium, musiały 
nieustannie dbać o rozwój gospodarczy, aby w ten sposób zgromadzić odpowiednie środki do walki z groźnym wrogiem. Koncepcja zgrywalizowanego przedmiotu jest efektem współpracy autorki z naukowcami z Uniwersytetu Gdańskiego: dr. Wojciechem Glacem oraz dr hab. Joanną Mytnik, prof. UG.

W ramach przedmiotu zastosowano m.in. następujące mechanizmy znane $\mathrm{z}$ gier: system punktowy, który zastąpił tradycyjne oceny (zamieniany na system ocen dopiero po zakończeniu każdego z semestrów); poziomy, które uczniowie osiągali, realizując różnego rodzaju aktywności; wyzwania - misje prowadzone przez uczniów, które zastąpiły tradycyjne zadania i ćwiczenia; opisaną fabułę (najważniejszy element w systemie grywalizacyjnym), która nadała zajęciom zabawowy charakter i scaliła wszystkie pozostałe mechanizmy w jedną całość; tabelę wyników - element stymulujący rywalizację między uczniami.

Doświadczenia z wdrożenia grywalizacji analiza czynników motywujących uczniów

W celu oceny wpływu zastosowanych w ramach przedmiotu podstawy przedsiębiorczości mechanizmów na motywację uczniów do uczenia się, po zakończeniu roku szkolnego 2019/2020 wśród uczniów, uczestników zgrywalizowanego przedmiotu, przeprowadzono badania. Celem było uzyskanie informacji o tym, jak postrzegają oni wdrożone w ramach przedmiotu mechanizmy grywalizacyjne, oraz o tym, jakie czynniki w ich opinii w największym stopniu wpływały na ich motywację do nauki i działania (realizacji różnych aktywności w ramach lekcji mających na celu rozwijanie ich wiedzy oraz kompetencji przedsiębiorczych).

Do badania wykorzystano metodę sondażu diagnostycznego. Zastosowano formularz ankiety, składający się z pytań zamkniętych jednokrotnego i wielokrotnego wyboru, a także z pytań otwartych. W badaniu wzięło udział 48 uczniów klas pierwszych (84\% wszystkich uczniów realizujących w roku szkolnym 2019/2020 przedmiot podstawy przedsiębiorczości) uczęszczających do Akademickiego Liceum Ogólnokształcącego w Rzeszowie. Przeprowadzone badanie miało charakter opisowy i diagnostyczny. Uczestnicy badania wyrazili swoją opinię, wykorzystując 5-stopniową skalę Likerta („zdecydowanie się nie zgadzam”, „nie zgadzam się”, „nie mam zdania”, „zgadzam się”, „zdecydowanie się zgadzam”).

Główny problem badawczy dotyczył opinii uczniów na temat zastosowanych mechanizmów grywalizacji, które w największym stopniu wpływały na ich motywację do podejmowania działania podczas lekcji.

W badaniu elementów środowiska przedmiotu, które w największym stopniu wpłynęły na motywację uczniów do działania, zastosowano model Octalysis Framework (ośmiokąt motywacji), opracowany przez Yu-Kai Chou (por. Freitas i in., 2017), w którym zdefiniowano osiem podstawowych czynników motywujących:

1. Działanie w imię wyższego celu (ang. Epic Meaning \& Calling) - potrzeba poczucia odpowiedzialności oraz potrzeba bycia zauważonym oraz docenionym.

2. Rozwój i osiąganie celów (ang. Development \& Accomplishment) - potrzeba rozwoju, osiągania celów i sukcesów, pokonywania wyzwań oraz radzenia sobie z trudnościami. 
3. Kreatywność i informacja zwrotna (ang. Empowerment of Creativity \& Feedback) potrzeba zaangażowania się w proces twórczy, tworzenia nowych rzeczy i pomysłów, a także potrzeba otrzymywania informacji zwrotnych.

4. Własność i posiadanie (ang. Ownereship \& Possession) - potrzeba posiadania czegoś i ulepszania tego.

5. Wpływ społeczny i nawiązywanie relacji (ang. Social Influence \& Relatedness) - obejmuje aspekty społeczne, takie jak: relacje towarzyskie, akceptacja społeczna, rywalizacja.

6. Niedostatek i niecierpliwość (ang. Scarcity \& Impatience) - potrzeba i przymus czekania.

7. Nieprzewidywalność i ciekawość (ang. Unpredictability \& Curiosity) - potrzeba zaspokojenia ciekawości, co będzie dalej.

8. Strach przed utratą i zapobieganie (ang. Loss \& Avoidance) - unikanie czegoś negatywnego np. porażki (Yu-kai Chou, 2015).

W ww. obszarach badani dokonali oceny, wybierając odpowiedź najlepiej odzwierciedlającą ich odczucia dotyczące poszczególnych motywatorów w skali od 1 do 5 (od „zdecydowanie się nie zgadzam” do „zdecydowanie się zgadzam”). W tabeli 1 zaprezentowano pytania, które znalazły się w kwestionariuszu ankietowym. Odzwierciedlają one środowisko Galaktyka Enterprise w kontekście ośmiu elementów modelu Octalysis Framework.

Tabela 1. Wyjaśnienie ośmiu czynników motywacyjnych w kontekście wdrożonej grywalizacji

\begin{tabular}{|c|c|}
\hline Czynnik motywujący & Pytanie w kwestionariuszu ankietowym \\
\hline 1. Działanie w imię wyższego celu & $\begin{array}{l}\text { Motywowała mnie walka ze Złowrogim Imperium - } \\
\text { miałam/em poczucie robienia czegoś dla większego } \\
\text { dobra }\end{array}$ \\
\hline 2. Rozwój i osiąganie celów & $\begin{array}{l}\text { Motywowało mnie zdobywanie punktów, } \\
\text { pokonywanie kolejnych poziomów rozwoju i rozwój } \\
\text { umiejętności }\end{array}$ \\
\hline 3. Kreatywność i informacja zwrotna & $\begin{array}{l}\text { Motywowało mnie odkrywanie nowych rzeczy, } \\
\text { nowej wiedzy, nowych narzędzi oraz otrzymywanie } \\
\text { informacji zwrotnej }\end{array}$ \\
\hline 4. Własność i posiadanie & $\begin{array}{l}\text { Motywowało mnie posiadanie własnej Planety, } \\
\text { którą musiałam/-em rozwijać, zdobywając punkty }\end{array}$ \\
\hline $\begin{array}{l}\text { 5. Wpływ społeczny i nawiązywanie } \\
\text { relacji }\end{array}$ & $\begin{array}{l}\text { Motywowały mnie współpraca } \mathrm{z} \text { innymi (w ramach } \\
\text { misji zespołowych i/lub całej klasy w walce } \\
\text { z Imperium), rywalizacja, atmosfera na zajęciach }\end{array}$ \\
\hline 6. Niedostatek i niecierpliwość & $\begin{array}{l}\text { Motywowała mnie potrzeba czekania na kolejne } \\
\text { misje tak, aby nie przegapić okazji }\end{array}$ \\
\hline 7. Nieprzewidywalność i ciekawość & $\begin{array}{l}\text { Motywowała mnie chęć dowiedzenia się, jakie } \\
\text { kolejne misje będą uruchomione, co będzie przede } \\
\text { mną }\end{array}$ \\
\hline 8. Strach przed utratą i zapobieganie & $\begin{array}{l}\text { Motywowała mnie chęć uniknięcia porażki, czyli } \\
\text { zdobycia małej ilości punktów (otrzymania niskiej } \\
\text { oceny) }\end{array}$ \\
\hline
\end{tabular}

Źródło: opracowanie własne 
Średnie oceny poszczególnych czynników motywacyjnych kształtowały się pomiędzy 2,8 a 4,0. Szczegółowe wyniki dotyczące ocen poszczególnych aspektów w grze Galaktyka Enterprise zaprezentowano w tabeli 2. W kolumnie trzeciej opisano poszczególne czynniki za pomocą ocen rankingowych otrzymanych przez przekształcenie tabeli średnich w tabelę rankingową.

Tabela 2. Ranking ocen czynników motywacyjnych

\begin{tabular}{|c|c|c|}
\hline \multicolumn{1}{|c|}{ Czynnik } & Średnia ocen & Ranking \\
\hline Czynnik 1 & 3,2 & 5 \\
\hline Czynnik 2 & 4,0 & 1 \\
\hline Czynnik 3 & 3,6 & 4 \\
\hline Czynnik 4 & 3,7 & 3 \\
\hline Czynnik 5 & 3,8 & 2 \\
\hline Czynnik 6 & 3,0 & 6 \\
\hline Czynnik 7 & 2,8 & 7 \\
\hline Czynnik 8 & 4,0 & 1 \\
\hline
\end{tabular}

Źródło: opracowanie własne

W celu czytelniejszej prezentacji powyższych danych na wykresie radarowym (rycina 1) dokonano przekształcenia tabeli rankingowej w odwróconą tabelę rankingową (czynnik mający w tabeli rankingowej najwyższą ocenę $1 \mathrm{w}$ odwróconej tabeli rankingowej otrzymał ocenę 7 itd.).

Rycina 1. Ocena czynników motywacyjnych przez uczniów

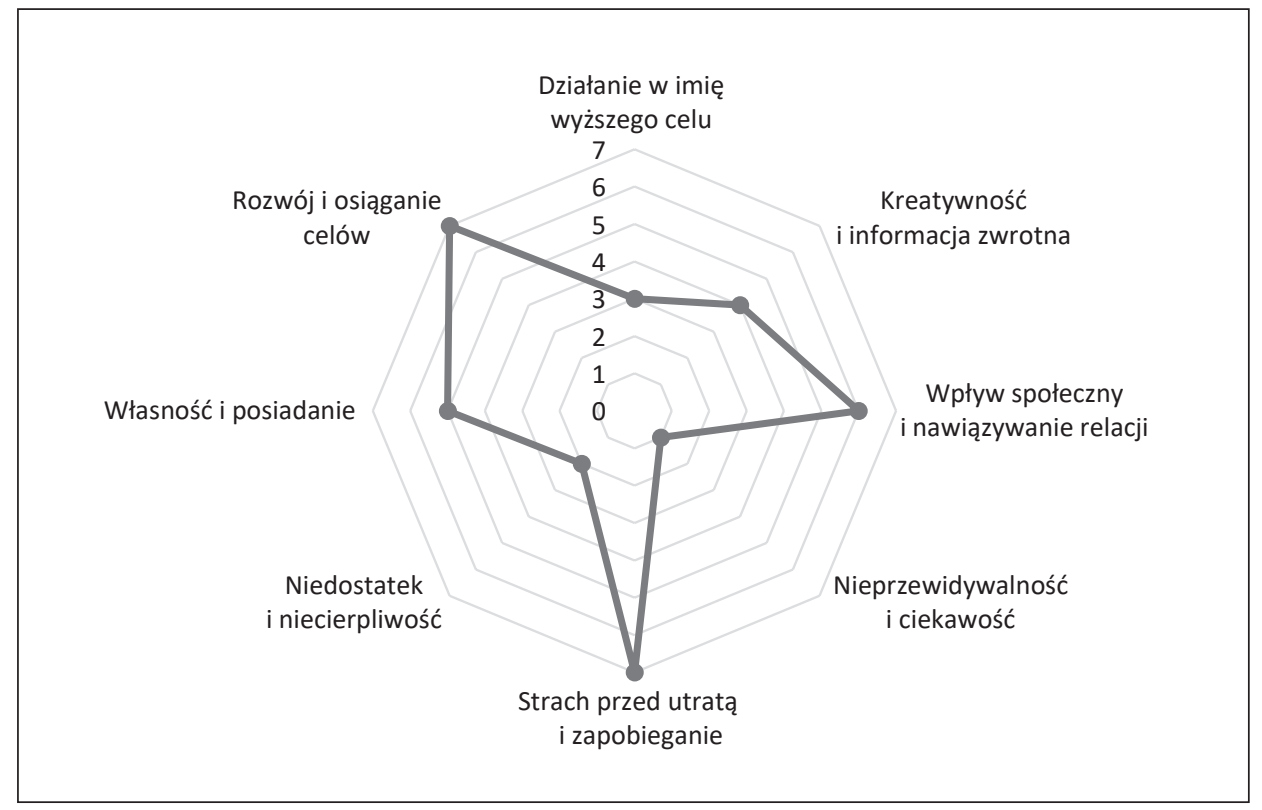

Źródło: opracowanie własne 
Analiza czynników, które w najwyższym stopniu motywowały uczniów do działania podczas realizacji podstawy programowej z wykorzystaniem grywalizacji, pozwala wyciągnąć wnioski, mogące stać się podstawą do dalszego ulepszania formuły gry. Dostosowanie elementów gry i jej zasad do potrzeb młodych ludzi jest czynnikiem kluczowym w skuteczności stosowania grywalizacji.

Wyniki badań pozwalają zauważyć, iż czynnikami motywacyjnymi w prezentowanej formule przedmiotu, które w największym stopniu determinowały działanie uczniów, były:

- strach przed utratą i zapobieganie - motywator odzwierciedlony chęcią uniknięcia sytuacji, w której uczeń zdobyłby niską liczbę punktów i w konsekwencji otrzymałby niską ocenę końcową z przedmiotu;

- rozwój i osiąganie celów - chęć zdobywania punktów rozwoju i populacji przyczyniających się do pokonywania kolejnych poziomów rozwoju swojej Planety, ale także rozwoju własnych umiejętności i wiedzy z obszaru przedsiębiorczości;

- wpływ społeczny i nawiązywanie relacji - zastosowane mechanizmy współpracy i rywalizacji z innymi uczniami/klasami, atmosfera na zajęciach;

- własność i posiadanie - zaangażowanie ucznia w dbanie o rozwój Planety, której był przywódcą.

Zgodnie z założeniami modelu Octalysis Framework, wśród czynników motywujących znajdują się czynniki związane $\mathrm{z}$ motywacją wewnętrzną oraz czynniki związane $z$ motywacją zewnętrzną. Prawa strona modelu przedstawionego na rycinie 1 reprezentuje czynniki związane z motywacją wewnętrzną. Są to: kreatywność i informacja zwrotna, wpływ społeczny i nawiązywanie relacji, nieprzewidywalność i ciekawość. Czynniki znajdujące się po lewej stronie reprezentują motywację zewnętrzną: rozwój i osiąganie celów, własność i posiadanie oraz niedostatek i niecierpliwość. Dodatkowo czynniki przedstawione w górnej części ośmiokąta postrzegane są jako te, które są związane z motywacją pozytywną, sprawiają, że uczestnik czuje się spełniony i zadowolony. Czynniki znajdujące się w dolnej części ośmiokąta związane są z motywacją negatywną, czyli takimi odczuciami, jak niepokój czy uzależnienie (Chou, 2015).

Analiza otrzymanych wyników pozwala na dalsze wnioskowanie dotyczące źródeł motywacji młodych ludzi. Wśród czynników, które w największym stopniu motywowały do działania, znalazł się jeden związany z motywacją wewnętrzną (wpływ społeczny i nawiązywanie relacji) oraz dwa związane z motywacją zewnętrzną (rozwój i osiąganie celów, własność i posiadanie). Chou podkreśla, iż w grywalizacji warto projektować doświadczenia tak, aby wykorzystywały motywację wewnętrzną użytkowników (Chou, 2015).

Większość głównych czynników motywacyjnych wskazanych przez uczniów należy do grupy czynników pozytywnych (górna część ośmiokąta). Można zauważyć jednak, iż czynnikiem silnie motywującym do działania był również czynnik mający negatywny charakter - strach przed utratą i zapobieganie. Wysoki wynik w tym obszarze sugeruje, że uczniowie motywowani są przez niepewność i strach przed zdobyciem niewystarczającej liczby punktów powodujące uzyskanie niskiej oceny końcowej z przedmiotu. Niestety ten typ motywacji jest efektem specyfiki polskiego systemu edukacji, w którym „nauczanie zostało podporządkowane ocenianiu - nawet rodzic nie pyta dziecka, czego się nauczyło, lecz czy było pytane i jaką dostało ocenę [... ]" (Ostrowska, 2009).

Równoważenie zewnętrznych i wewnętrznych motywatorów jest szczególnym wyzwaniem, które staje przed nauczycielem wdrażającym grywalizację na zajęciach. Dzięki 
motywacji wewnętrznej uczestnicy gry nie potrzebują nagród, aby zaangażować się w proces uczenia się. Oparcie grywalizacji na silnej motywacji zewnętrznej uczestników generować będzie rezultaty krótkoterminowe i może prowadzić do negatywnego efektu „nadmiernego uzasadnienia” (ang. overjustification effect) (Chou, 2015). Zewnętrzne motywatory (takie jak nagrody, oceny czy wyznaczane przez nauczyciela cele) zaczną przesłaniać wewnętrzne przyczyny podejmowania działań przez uczniów, a w efekcie - utratę wewnętrznej motywacji do uczenia się.

\section{Podsumowanie}

Szkoły, które kształcą młodych ludzi, stoją przed poważnymi wyzwaniami związanymi z potrzebą zwiększania zaangażowania się młodych ludzi w proces uczenia się oraz zwiększenia ich motywacji. Grywalizacja jest metodą, która daje możliwości odkrywania i zdobywania nowej wiedzy i umiejętności przy jednoczesnym zwiększeniu motywacji uczestników gry do uczenia się. Autorka artykułu zaprezentowała ideę zgrywalizowanego przedmiotu podstawy przedsiębiorczości oraz wykorzystane w nim mechanizmy, które wspierały motywację do nabywania wiedzy i rozwijania kompetencji uczniów realizujących podstawę programową. Autorka zdiagnozowała również główne czynniki, które motywowały uczniów biorących udział w grze, wykorzystując model Octalysis Framework. Uzyskane wyniki badania pokazują, iż czynnikami, które w grywalizacji w największym stopniu motywowały uczniów do działania, były: rozwój i osiąganie celów, strach przed utratą i zapobieganie, wpływ społeczny i nawiązywanie relacji oraz własność i posiadanie. Silnie motywujący okazał się również czynnik strach przed utratą i zapobieganie, co sugeruje, że w polskiej szkole nauczanie nadal podporządkowane jest ocenianiu. Równoważenie zewnętrznych i wewnętrznych czynników wpływających na motywację uczniów jest wyzwaniem, przed którym staje nauczyciel wdrażający grywalizację na swoich zajęciach.

Autorka widzi potrzebę dalszych badań i analiz w zakresie wykorzystania grywalizacji w nauczaniu przedsiębiorczości. Możliwe jest rozszerzenie obszaru badawczego o szkolnictwo wyższe, co umożliwiłoby porównanie hierarchii i istotności czynników motywacyjnych dwóch grup młodzieży, tj. uczniów i studentów. Znajomość tych czynników pozwoli w przyszłości na opracowanie sposobów wprowadzania ulepszeń w zakresie mechanizmów, które mogą być wykorzystane podczas grywalizacji kolejnych przedmiotów/ kursów.

Literatura

References

Barata, G., Gama, S., Jorge, J., Gonçalves, D. (2015). Gamification for smarter learning: Tales from the trenches. Smart Learning Environments, 2(1), 10, 1-23. doi: 10.1186/s40561-015-0017-8

Borowiec-Gabryś, M., Kilar, W., Rachwał, T. (2018). Przedsiębiorczość jako kompetencja przyszłości. W: S. Kwiatkowski (red.), Kompetencje przyszłości. Warszawa: FRSE, 68-89.

Boyle, E.A., MacArthur, E.W., Connolly, T.M., Hainey, T., Manea, M., Kärki, A., Van Rosmalen, P. (2014). A narrative literature review of games, animations and simulations to teach research methods and statistics. Computers \& Education, 74, 1-14. doi: 10.1016/j.compedu.2014.01.004 
Bozkurt, A., Sharma, R.C. (2020). Emergency remote teaching in a time of global crisis due to CoronaVirus pandemic. Asian Journal of Distance Education, 15(1), 1-6. doi: 10.5281/zenodo.3778083

Chou, Y.K. (2015). Actionable Gamification: Beyond Points, Badges, and Leaderboards. Fremont: Octalysis.

Connolly, T.M., Boyle, E.A., MacArthur, E., Hainey, T., Boyle, J.M. (2012). A systematic literature review of empirical evidence on computer games and serious games. Computers and Education, 59(2), 661-686. doi: 10.1016/j.compedu.2012.03.004

Deterding, S., Sicart, M., Nacke, L., O’Hara, K., Dixon, D. (2011). From Game Design Elements to Gamefulness: Defining Gamification. Proceedings of the 2011 Annual Conference Extended Abstracts on Human Factors in Computing Systems - CHI EA '11, 2425, 9-15. doi:10.1145/1979742.1979575

Drucker, P.F. (1985). Innovation and entrepreneurship. New York: Harper \& Row.

Freitas, S.A.A., Lacerda, A.R.T, Calado, P.M.R.O., Lima, T.S., Dias Canedo, E. (2017). Gamification in education: A methodology to identify student's profile. 2017 IEEE Frontiers in Education Conference (FIE). Indianapolis, 1-8, doi: 10.1109/FIE.2017.8190499

Gąsiorowska-Mącznik, E. (2017). Teoretyczne podstawy przedsiębiorczości. Nierówności Społeczne a Wzrost Gospodarczy, 52(4), 392-403. doi: 10.15584/nsawg.2017.4.28

Hanus, M.D., Fox, J. (2015). Assessing the effects of gamification in the classroom: A longitudinal study on intrinsic motivation, social comparison, satisfaction, effort, and academic performance. Computers \& Education, 80, 152-161. doi: 10.1016/j.compedu.2014.08.019

Kachniewska, M. (2015). Potencjał mediów społecznościowych w obszarze popularyzacji aktywności turystycznej. Rozprawy Naukowe Akademii Wychowania Fizycznego we Wrocławiu, 50, 35-48.

Kaźmierczak, K. (2016). Grywalizacja - od rutyny do zabawy dajacej efekty. Warszawa: Wiedza i Praktyka.

Kilar, W., Rachwał, T. (2019a). Przedsiębiorczość w edukacji przedszkolnej i szkole podstawowej w warunkach zmian podstawy programowej. W: T. Rachwał (red.), Kształtowanie kompetencji przedsiębiorczych, t. 5. Warszawa: Fundacja Rozwoju Systemu Edukacji, 122-141.

Kilar, W., Rachwał, T. (2019b). Przedsiębiorczość w szkole średniej w warunkach reformy systemu oświaty. W: T. Rachwał (red.), Kształtowanie kompetencji przedsiębiorczych, t. 5. Warszawa: Fundacja Rozwoju Systemu Edukacji, 186-198.

Kumar, B., Khurana, P. (2012). Gamification in Education - Learn Computer Programming with Fun. International Journal of Computers and Distributed Systems, 2(1), 46-53.

Kuratko, D.F. (2005). The Emergence of Entrepreneurship Education: Development, Trends, and Challenges. Entrepreneurship Theory and Practice, 29(5), 577-597. doi:10.1111/j.15406520.2005.00099.x

Kwiatkowski, S.M. (2018). Kompetencje przyszłości. W: S.M. Kwiatkowski (red.), Kompetencje przyszłości. Warszawa: Fundacja Rozwoju Systemu Edukacji, 14-29.

Marques, L.A., Albuquerque, C. (2012). Entrepreneurship Education and the Development of Young People Life Competences and Skills. Journal of Entrepreneurship Perspectives, 1(2), 55-68.

Nand, K., Baghaei, N., Casey, J., Barmada, B., Mehdipour, F., Liang, H.N. (2019). Engaging children with educational content via Gamification. Smart Learning Environments, 6(6), 1-15. doi: 10.1186/ s40561-019-0085-2

Ostrowska, M. (2009, 15 lutego). Jaka jest wspótczesna szkoła?. Pozyskano z: http://ostrowska.edu. pl/2009/02/jaka-jest-wspolczesna-szkola/

Piróg, D. (2015). Kompetencje z zakresu przedsiębiorczości: rozważania teoretyczne i ich ilustracje w obszarze szkolnictwa wyższego. Przedsiębiorczość - Edukacja [Entrepreneurship - Education], 11, 364-376.

Qian, M., Clark, K.R. (2016). Game-based Learning and 21st century skills: A review of recent research. Computers in Human Behavior, 63, 50-58. doi: 10.1016/j.chb.2016.05.023

Rachwał, T. (red.). (2019). Kształtowanie kompetencji przedsiębiorczych. Seria Naukowa, 5, Warszawa: Fundacja Rozwoju Systemu Edukacji. 
Rachwał, T., Kilar, W., Kawecki, Z., Wróbel, P. (2018). Edukacja w zakresie przedsiębiorczości w wychowaniu przedszkolnym, szkole podstawowej i szkołach średnich w świetle nowej podstawy programowej. Przedsiębiorczość - Edukacja [Entrepreneurship - Education], 14, 389-424.

Sadowska, M. (2016). Edukacja w zakresie przedsiębiorczości w polskim systemie kształcenia oraz w państwach europejskich. International Entrepreneurship Review, 2(1), 149-164.

Sánchez, D.R., Langer, M., Kaur, R. (2020). Gamification in the classroom: Examining the impact of gamified quizzes on student learning. Computers \& Education, 144, 1-16. doi: 10.1016/J. COMPEDU.2019.103666

Tkaczyk, P. (2012). Grywalizacja: jak zastosować mechanizmy gier w działaniach marketingowych. Gliwice: Onepress.

Wach, K. (2014). Edukacja dla przedsiębiorczości: pomiędzy przedsiębiorczą pedagogiką a edukacją ekonomiczną i biznesową. Horyzonty Wychowania, 13(28), 11-32.

Wach, K. (2013). Edukacja na rzecz przedsiębiorczości wobec współczesnych wyzwań cywilizacyjno-gospodarczych. Przedsiębiorczość - Edukacja [Entrepreneurship - Education], 9, 246-257.

Wach, K., Głodowska, A. (2019). The Role of University in the Development of Entrepreneurial Intentions of Younger Generations: Selected Models. W: M. Pietrzykowski (red.), Fostering Entrepreneurial and Sales Competencies in Higher Education. Poznań: Bogucki Wydawnictwo Naukowe, 45-63. doi: 10.12657/9788379862801-4

Zioło, Z. (2012). Miejsce przedsiębiorczości w edukacji. Przedsiębiorczość - Edukacja [Entrepreneurship - Education], 8, 10-23. doi: 10.24917/20833296.8.1

Joanna Świętoniowska, dr, Wyższa Szkoła Informatyki i Zarządzania w Rzeszowie, Kolegium Zarządzania, Katedra Zarządzania. Jej zainteresowania naukowe ukierunkowane są na problematykę związaną z zarządzaniem projektami, innowacjami, przedsiębiorczością oraz wykorzystaniem grywalizacji i gier planszowych w edukacji. Jest dyrektorem Centrum Zaawansowanych Technologii Dydaktycznych na uczelni. Jest współautorką gry planszowej oraz gry online Fabryka Aut, kształtującej najważniejsze umiejętności w zakresie zarządzania projektami. Od 2019 r. prowadzi przedmiot podstawy przedsiębiorczości, realizowany w formie zgrywalizowanej.

Joanna Świętoniowska, PhD, University of Information Technology and Management in Rzeszow, Collegium of Management, Chair of Management. Her research interests are related to management, innovation, entrepreneurship and the use of gamification and board games in education. She is the Director of the Center for Advanced Teaching Technologies at the university. She is a coauthor of the board game and the online game Car Factory, reflecting the key elements of project management. Since 2019, she has been teaching the subject of Entrepreneurship in a gamified form.

ORCID: https://orcid.org/0000-0003-2355-915X

\section{Adres/Address:}

Wyższa Szkoła Informatyki i Zarządzania w Rzeszowie

Kolegium Zarządzania

Katedra Zarządzania

ul. Sucharskiego 2

35-225 Rzeszów, Poland

e-mail: jswietoniowska@wsiz.edu.pl 